\title{
Milk yield persistency and its relationship with health problems in Holstein dairy cows supplemented with different levels of ruminally protected methionine and choline
}

\author{
MEHRNAZ ARDALAN, MEHDI DEHGHAN-BANADAKY and KAMRAN REZAYAZDI
}

Department of Animal Science, University College of Agriculture and Natural Resources, University of Tehran, Karaj, Iran

\begin{abstract}
Forty Holstein dairy cows in their first and second lactation were used in a lactation study from 4-week prepartum through 14-week postpartum to investigate the potential effect of feeding different levels of ruminally protected methionine and choline on milk yield persistency of Holstein dairy cows. Cows were randomly assigned to receive one of the following treatments: $18 \mathrm{~g} / \mathrm{d}$ of rumen-protected methionine (RPM), $60 \mathrm{~g} / \mathrm{d}$ of rumenprotected choline (RPC), $18 \mathrm{~g} / \mathrm{d}$ of RPM $+60 \mathrm{~g} / \mathrm{d}$ of RPC, or neither supplement (control). The use of polynomial equations revealed that the polynomial coefficients of regression were closer $(P<0.05)$ to zero for RPM+RPC-fed cows than for other cows. Therefore, RPM+RPC-fed cows had a more persistent $(P<0.05)$ early-lactation milk yield than did other cows. Cows fed RPM+RPC had the lowest health problems compared with other groups. The treatments significantly affected actual milk yield $(P<0.05), 4 \%$ fat-corrected milk (FCM) $(P<0.01)$ and energy-corrected milk $(E C M)(P<0.01)$ across lactation weeks. The treatments significantly affected average dry matter intake (DMI) for the first 14 week postpartum $(P<0.05)$. Also, treatments significantly affected lactose percentage of milk across lactation weeks $(P<0.01)$. In general, it was expected that RPM+RPC-fed cows with greater persistency of lactation would be healthier because the incidence of metabolic and reproductive disorders and negative energy balance that originate from the physiological stress of high milk yield would be lower.
\end{abstract}

Keywords: Holstein dairy cows, persistency, milk yield, rumen-protected choline, rumen-protected methionine

\section{Zusammenfassung}

\section{Milchleistung und deren Persistenz sowie Beziehungen zu Gesundheitsmerkmalen bei einer Futterergänzung mit pansengeschütztem Methionin und Cholin bei Holsteinkühen}

An 40 Holsteinkühen mit erster und zweiter Laktation wurde im Zeitraum von vier Wochen vor bis 14 Wochen nach der Geburt der Einfluss einer Futterergänzung mit pansengeschütztem Methionin und Cholin auf Milchleistung und deren Persistenz untersucht. Es erhielten nach dem Zufallsprinzip ausgewählte Tiere in den drei Gruppen I. $18 \mathrm{~g} /$ Tag pansengeschütztes Methionin (RPM), II. $60 \mathrm{~g} /$ Tag pansengeschütztes Cholin (RPC) 
und III. $18 \mathrm{~g} / \mathrm{Tag}$ RPM $+60 \mathrm{~g} / \mathrm{Tag}$ RPC neben einer Kontrollgruppe ohne Zusatz. Signifikant höhere Erstlingsmilchleistung und Persistenz erreichte die Gruppe RPM+RPC. Die Gruppe III wies auch gegenüber I. und II. die geringsten Gesundheitsprobleme auf so dass bei diesen Tieren fanden keine Behandlungsnotwendigkeiten bestanden. Signifikante Einflüsse der Futterergänzungen ergaben sich auch bei der täglichen Trockenfutteraufnahme und beim Laktoseanteil. Im Allgemeinen war zu erwarten, dass bei III. mit besserer Persistenz das Auftreten metabolischer und reproduktiver Störungen verbunden mit einer negativen Energiebilanz durch physiologische Belastung einer höheren Milchleistung niedriger ausfallen würde.

Schlüsselwörter: Holstein, Milchkuh, Milchleistung, Persistenz, pansengeschütztes Methionin, pansengeschütztes Cholin

\section{Introduction}

Persistency of lactation can be defined as the ability of a cow to maintain milk production after peak yield, with cows being persistent if they tend to maintain their peak yield within a lactation period (SWALVE 1995, BAFFOUR-AWUAH et al. 1996, TAKMA and AKBAS 2007). Improved persistency of lactation can contribute to reducing the cost of the production system because lactation persistency is associated with feeding and health costs, reproductive performance, resistance to disease and the return from milk considering a 305day production cycle (SÖLKNER and FUCHS 1987, DEKKERS et al. 1996, 1998, SWALVE and GUO 1999).

Choline is sometimes classified as a B vitamin, even though it does not fulfil the standard vitamin definition, and is an essential nutrient when excess methionine and folate are not available (NRC 1998). The microbial populations in the rumen quickly degrade dietary choline; therefore, the only practical means of increasing choline to the dairy cows is to feed it in a rumen-protected form (Rumen-protected choline=RPC). Methionine has been identified as one of the most limiting amino acid for the synthesis of milk and milk protein by dairy cows fed diets based on corn (OVERTON et al. 1998). One approach that has been used to supply additional methionine to the cow has been to protect it from ruminal degradation for subsequent absorption in the small intestine. The pathways of methionine and choline metabolism are interrelated. Methionine is the source of the methyl donor S-adenosylmethionine, the metabolite that provides methyl groups for the de novo synthesis of choline.

To our knowledge, there were not any researches regarding to the study of the effects of rumen-protected choline and methionine on the persistency of lactation. Therefore, the objective of present study was to investigate the potential effects of supplementing ruminally protected forms of methionine and choline to the diets of Holstein dairy cows on milk yield persistency and production performance in the first 14 weeks of lactation. 


\section{Material and methods}

\section{Cows, treatments and experimental design}

Forty Holstein dairy cows in their first $(n=24)$ and second $(n=16)$ lactation were used in a lactation study from 4-week prepartum (body condition score, $B C S=3.6 \pm 0.04$; mean $\pm S E$ ) through 14-week postpartum. Selection of cows for initializing this experiment was based on parity, milk yield of previous lactation (milk yield of dams for the cows in their first lactation), and body condition score. Iranian Holsteins are either descendants of the cows originally imported from North America and Europe or Holstein upgrades of domestic breeds over 50 years. The dairy cows used in this study are among the purebred Holsteins managed under conditions similar to those in most other developed countries. Cows ( 10 cows per treatment $=6$ cows in the first lactation and 4 cows in second lactation) were randomly assigned to receive one of the following treatments: $18 \mathrm{~g} / \mathrm{d}$ of rumen-protected methionine (RPM), $60 \mathrm{~g} / \mathrm{d}$ of RPC, $18 \mathrm{~g} / \mathrm{d}$ of RPM $+60 \mathrm{~g} / \mathrm{d}$ of RPC, and neither supplement (control). The RPM product (SmartamineM [Adisseo, Antony, France]) was a white solid granular powder coated with a polymer (2-vinyl pyridine-Co Styrene) sensitive to acidic $\mathrm{pH}$ in abomasum, and contained $75 \%$ DL-methionine. The RPC product (COL 24 [Soda Feed Ingredients, Monaco, France]) is a rumen-protected source of choline chloride. COL 24 is produced by encapsulating choline chloride with a coating matrix able to resist rumen breakdown and release choline in the intestine and contained $24 \%$ choline chloride. The DM-based forage to concentrate ratio was 57:43 for dry period diet and 44:56 for lactation diet. The RPM and RPC were top dressed onto the TMR. Cows were fed for ad libitum intake the total mixed diets. Three times weekly, samples of both the dry-cow and lactating-cow TMR diets were taken and frozen until samples were ready to be dried. Similarly, orts samples were also taken 3 times weekly on days that feed samples were not taken. Feed and orts samples were collected from 4 week before expected calving dates until 14 week into lactation. All samples were dried at $60^{\circ} \mathrm{C}$ for $72 \mathrm{~h}$, and then weighed to determine moisture loss. Dried samples were ground through 1-mm screen and the nutrient contents of samples were analyzed monthly. Chemical analyses of samples were based on the AOAC Official Method (2000) number 925.40 for DM, 923.03 for ash, 984.13 for CP and 972.16 for total fat. Neutral detergent fibre (NDF) and acid detergent fibre (ADF) were determined as described by VAN SOEST et al. (1991). The NDF was assayed with a heat-stable amylase and both NDF and ADF are expressed inclusive of residual ash. Non-fibre carbohydrate (NFC) was calculated as the difference between 100 and the sum of CP, NDF, total fat, and ash. Rations were then adjusted accordingly to maintain consistent nutrient levels. Amounts of feed offered and refused were measured daily throughout the experiment, and weekly analyses of DM content of the TMR were used to calculate DMI. Prepartum and postpartum diets (Tables 1 and 2) were formulated using the CNCPS program. 
Table 1

Ingredient composition of pre- and postpartum diets (\% of DM)

Futterzusammensetzung vor und nach der Geburt (\% DM)

\begin{tabular}{lcc}
\hline Ingredient & Prepartum TMR & Postpartum TMR \\
\hline Alfalfa hay & 36.00 & 17.81 \\
Corn silage & 20.89 & 25.84 \\
Barley grain & 10.44 & 17.39 \\
Corn grain & 5.22 & 7.61 \\
Soybean meal & 10.68 & 7.79 \\
Wheat bran & 10.56 & 6.60 \\
Whole cottonseed & - & 6.82 \\
Canola meal & - & 6.82 \\
Beet pulp & 3.60 & - \\
Minerals and vitamins supplement ${ }^{1}$ & 0.78 & 0.61 \\
Salt & 0.16 & 0.49 \\
Calcium carbonate & - & 0.37 \\
Sodium bicarbonate & - & 0.62 \\
Fat supplement & - & 1.23 \\
Ammonium chloride & 0.27 & - \\
Calcium chloride & 1.16 & - \\
Magnesium sulfate & 0.23 & - \\
\hline
\end{tabular}

${ }^{1}$ contained $180 \mathrm{~g} / \mathrm{kg} \mathrm{Ca}, 70 \mathrm{~g} / \mathrm{kg} \mathrm{P}, 30 \mathrm{~g} / \mathrm{kg} \mathrm{Mg}, 4 \mathrm{~g} / \mathrm{kg} \mathrm{Fe}, 0.5 \mathrm{~g} / \mathrm{kg} \mathrm{Cu}, 5 \mathrm{~g} / \mathrm{kg} \mathrm{Mn}, 4 \mathrm{~g} / \mathrm{kg} \mathrm{Zn}, 0.1 \mathrm{~g} / \mathrm{kg} \mathrm{Co}, 0.1 \mathrm{~g} / \mathrm{kg} \mathrm{l}$, $0.03 \mathrm{~g} / \mathrm{kg} \mathrm{Se}, 0.4 \mathrm{~g} / \mathrm{kg}$ antioxidant, $5 \times 10^{5} \mathrm{IU} / \mathrm{kg}$ of vitamin $\mathrm{A}, 10^{5} \mathrm{IU} / \mathrm{kg}$ of vitamin $\mathrm{D}$, and $2 \times 10^{3} \mathrm{IU} / \mathrm{kg}$ of vitamin $\mathrm{E}$

Table 2

Chemical composition of pre- and postpartum diets

Chemische Futterzusammensetzung vor und nach der Geburt

\begin{tabular}{lcc}
\hline Item & Prepartum TMR & Postpartum TMR \\
\hline DM, \% & 66.0 & 62.0 \\
CP, \% & 15.0 & 16.0 \\
Ash, \% & 8.9 & 7.1 \\
Total fat, \% & 2.4 & 5.1 \\
NDF, \% & 37.6 & 34.1 \\
ADF, \% & 27.8 & 20.8 \\
NFC, \% & 36.1 & 37.7 \\
Ca, \% & 0.89 & 0.56 \\
P, \% & 0.41 & 0.45 \\
NEL, Mcal/kg & 1.43 & 1.63 \\
RUP, \% of CP & 27.1 & 34.5 \\
RDP, \% of CP & 72.9 & 65.5 \\
Met, \% & 1.94 & 1.82 \\
Lys, \% & 6.60 & 6.42 \\
\hline
\end{tabular}

\section{Milking and milk composition analysis}

Cows were milked three times daily in a milking parlour at $06.00,14.00$, and 22.00 , with no provision of water or concentrate while milking. Milk yield was recorded weekly for all cows. The milk samples from individual cows were sent to the laboratory weekly for the analysis of milk percentages of fat, protein and lactose by Milk-O-Scan (Foss Electric, Denmark). $4 \%$ fat corrected milk $(F C M)$ of each cow was calculated as follows: $F C M=([0.4 \times k g$ milk $]+$ $[0.15 \times \mathrm{kg}$ milk $\times$ fat $\%])$. The yield of energy corrected milk (ECM) was calculated by the following formula): $\mathrm{ECM}=([0.327 \times \mathrm{kg}$ milk $]+[12.95 \times \mathrm{kg}$ fat $]+[7.2 \times \mathrm{kg}$ protein $])$. 
Also, some of the health problems were recorded during the trial, including incidence of dystocia, mastitis, retained placenta, displaced abomasum, ketosis, milk fever, foot/leg problems, and uterine problems.

\section{Statistical Analysis}

The weekly milk yield data were regressed against time (week of lactation) for individual cows, using the Reg procedure of SAS (SAS 2002). The resulting polynomial regression coefficients (linear and quadratic) were then subjected to variance analysis (ALLEN et al. 1983, MORRIS 1999), using GLM procedure of SAS (SAS 2002). The following model equation of polynomial regression was fitted for expressing the regression of weekly milk yield against time:

$$
Y_{i}=\beta_{0}+\beta_{1} X_{i}+\beta_{2} X_{i}^{2}+e_{i}
$$

where $Y_{i}$ is the response variable or weekly milk yield that can be predicted by a polynomial function of a regressor variable $X$ or week of lactation, $\beta_{0}$ is the intercept parameter, $\beta_{1}$ is the linear regression coefficient (the slope due to $X$ ), $\beta_{2}$ is the quadratic regression coefficient (the slope due to $X^{2}$ ); and $e_{i}$ is the residual effect.

The regression approach accounts for individual differences in lactation cycle that if analyzed solely as typical repeated measures using raw data may undervalue the intercow diversity of lactation curves. The polynomial coefficients would reflect the curvature of milk yield during the study (ALLEN et al. 1983, MORRIS 1999) i.e., the closer the coefficients to zero, the more persistent trend in milk yield, or the less dramatic drops and rises in lactation curve. Also, because the incidences of health problems were coded as a dichotomous variable $(0=$ health; $1=$ disease), a logistic regression model was used to analyze the effect of treatments on the incidence of health problems, using the maximum likelihood method of the LOGISTIC procedure of SAS (SAS 2002). The general equation of logistic regression model was defined as follows:

$$
\operatorname{Logit}(\pi)=a+\beta_{1} X_{1}+\beta_{2} X_{2}+\ldots+\beta_{n} X_{n}
$$

where $\pi$ is the odds of health problem, $a$ is the intercept parameter; $\beta_{1}$ to $\beta_{n}$ were the logistic regression coefficients for the explanatory effects, i.e. treatment effects, $\left(X_{1}\right.$ to $\left.X_{n}\right)$ included in the statistical model.

The repeated measurements of milk yield and composition and DMI were analyzed as a linear mixed model (Proc Mixed) with the best fitted covariance structure of SAS (SAS 2002). The least square means were estimated by Restricted Maximum Likelihood method. The statistical model included the effects of treatment, parity, time (week of lactation for milk yield and composition and DMI), and treatment $\times$ time. The covariance structure used to analyze the repeated measures of milk yield and components and DMI was first-order heterogeneous autoregressive structure, as it produced the least Akaikess Information Criterion (AIC). Week of lactation for milk yield and composition and DMI were used in the REPEATED statement with cow within treatment as the error term. Where significant, treatment means were separated using PDIFF option of SAS (SAS 2002). Acceptable significant levels were declared at $P<0.05$. 


\section{Results and discussion}

The use of polynomial equations to regress the actual milk yield of individual cows against lactation weeks revealed that linear, quadratic and cubic coefficients of regression were closer $(P<0.05)$ to zero for RPM+RPC-fed cows than for other cows (Table 3$)$. The simultaneous significant effects of RPM and RPC on the curvature of lactation arch were confirmed by the variance analysis of the polynomial coefficients (Table 3). From statistical perspective, intercept is equal to the mean of response variable or milk yield (STEEL and TORRIE 1987), therefore, as shown in Table 3, the intercept parameter was greater for RPM+RPC-fed cows and in conclusion, the actual milk yield tended to be greater for RPM+RPC-fed cows than other groups $(P<0.05)$. A closer polynomial coefficient to zero would reflect a more persistent early-lactation milk yield. Therefore, RPM + RPC-fed cows had a more persistent $(P<0.05)$ early-lactation milk yield than did other cows. Phenotypic variation in the shape of the lactation curve can influence dairy farm profitability (DEKKERS et al. 1996, GENGLER 1995). Cows with lower peak yield and greater persistency of lactation may be healthier because the incidence of metabolic and reproductive disorders and negative energy balance that originate from the physiological stress of high milk yield would be lower (TEKERLY et al. 2000, SÖLKNER and FUCHS 1987, DEKKERS et al. 1996, 1998, PRYCE et al. 1997, GROSSMAN et al. 1999). In addition, nutritional demands of such cows can be satisfied by rations consisting of a higher proportion of roughage, and this may decrease feed costs. Animals with very high peak yields are not able to consume adequate amounts of nutrients in the first part of lactation. This causes negative energy balances, reduces reproductive efficiency and increases susceptibility to diseases (SWALVE 2000, JAKOBSEN et al. 2002). An abrupt decline in milk yield after peak increases production costs because yield is distributed less equally over the complete lactation (GENGLER 1996, KOCAK and EKIZ 2008).

Table 3

Regression coefficients of early-lactation curve in control, RPM, RPC and RPM + RPC-fed cows

Regressionskoeffizienten der Anfangslaktationskurve bei den Versuchsgruppen

\begin{tabular}{|c|c|c|c|c|c|}
\hline \multirow{2}{*}{ Item } & \multicolumn{4}{|c|}{ Treatment } & \multirow{2}{*}{ SE } \\
\hline & Control & RPM & RPC & $\mathrm{RPM}+\mathrm{RPC}$ & \\
\hline Intercept & $34.40^{c}$ & $38.98^{\mathrm{b}}$ & $37.71^{\mathrm{b}}$ & $40.47^{a}$ & 1.12 \\
\hline Linear coefficient & $0.648^{c}$ & $0.443^{\mathrm{ab}}$ & $0.496^{\mathrm{b}}$ & $0.405^{\mathrm{a}}$ & 0.05 \\
\hline Quadratic coefficient & $-0.0068^{c}$ & $-0.0042^{b}$ & $-0.0047^{b}$ & $-0.0031^{\mathrm{a}}$ & 0.001 \\
\hline
\end{tabular}

RPM Rumen-protected methionine, RPC Rumen-protected choline, a,b,c Coefficients with different superscripts differ significantly $(P<0.05)$.

The treatments significantly affected actual milk yield, FCM, and ECM across lactation weeks $(P<0.05$; Table 4$)$. The actual milk yield $(P<0.05)$, FCM $(P<0.01)$, and ECM $(P<0.01)$ were greater for RPM+RPC-fed cows than other groups. Second-calf cows had greater actual milk yield, FCM, and ECM than cows in their first lactation $(P<0.001)$. The treatments significantly affected average postpartum DMI $(P<0.05)$, with no treatment by time interaction (Table 4). But there was no significant effect of treatments on prepartum DMI. Postpartum DMI was greater for RPM+RPC-fed cows. As expected, there was a significant parity effect on postpartum DMI with cows in their second lactation 
consuming more $\mathrm{DM}(P<0.01)$ than cows in their first lactation. Fat percentage of milk was greater for RPM+RPC-fed cows than other groups, but this effect was not significant. Also, cows in their first lactation had greater milk percentage of fat than cows in their second lactation $(P<0.01)$. Although, the treatments did not significantly affect protein percentage of milk, RPM-fed cows had greater percentage of milk protein, which suggested that methionine was the first limiting amino acid for milk protein synthesis. Also, treatments significantly affected lactose percentage of milk across lactation weeks $(P<0.01)$ and RPC-fed cows had the greatest amount. In general, the treatment $\times$ time had not any significant effect on milk yield and composition and DMI.

Table 4

The effects of supplemental rumen-protected methionine and choline on DMI and productive indices of lactating dairy cows across the lactation weeks

Auswirkungen des Futterzusatzes (RPM und RPC) auf Milchleistungsmerkmale und Trockensubstanzaufnahme in den Laktationswochen

\begin{tabular}{lccccccccc}
\hline \multirow{2}{*}{ Item } & \multicolumn{4}{c}{ Treatment } & \multirow{2}{*}{ SEM } & \multicolumn{4}{c}{$P$-value } \\
& Control & RPM & RPC & RPM+RPC & & Trt & Parity & Time & Trt $\times$ Time \\
\hline Milk, kg/d & $30.71^{\mathrm{c}}$ & $32.64^{\mathrm{bc}}$ & $34.23^{\mathrm{ab}}$ & $35.14^{\mathrm{a}}$ & 0.97 & 0.014 & $<0.001$ & $<0.001$ & 0.999 \\
$4 \% \mathrm{FCM}, \mathrm{kg} / \mathrm{d}$ & $26.55^{\mathrm{c}}$ & $28.59^{\mathrm{bc}}$ & $30.37^{\mathrm{ab}}$ & $31.40^{\mathrm{a}}$ & 1.06 & 0.003 & $<0.001$ & 0.016 & 0.943 \\
$\mathrm{ECM}, \mathrm{kg} / \mathrm{d}$ & $29.28^{\mathrm{c}}$ & $31.47^{\mathrm{bc}}$ & $33.21^{\mathrm{ab}}$ & $34.34^{\mathrm{a}}$ & 1.10 & 0.004 & $<0.001$ & 0.001 & 0.983 \\
Fat, \% & 3.29 & 3.30 & 3.28 & 3.39 & 0.03 & 0.904 & 0.006 & $<0.001$ & 0.900 \\
Protein, \% & 3.10 & 3.16 & 3.09 & 3.12 & 0.02 & 0.364 & 0.275 & $<0.001$ & 0.777 \\
Lactose, \% & $4.77^{\mathrm{b}}$ & $4.81^{\mathrm{b}}$ & $4.98^{\mathrm{a}}$ & $4.78^{\mathrm{b}}$ & 0.05 & 0.002 & 0.733 & $<0.001$ & 1.000 \\
Prepartum DMI, kg/d & 12.8 & 13 & 13 & 13.1 & 0.06 & 0.235 & 0.151 & 0.122 & 0.092 \\
Postpartum DMI, kg/d & $16.4^{\mathrm{a}}$ & $18.7^{\mathrm{b}}$ & $20.8^{\mathrm{c}}$ & $23.3^{\mathrm{d}}$ & 1.47 & $<0.001$ & $<0.001$ & $<0.001$ & 0.054 \\
\hline
\end{tabular}

Trt treatment, RPM rumen-protected methionine, RPC rumen-protected choline, a,b,c,d Means with different superscripts at each row differ significantly $(P<0.05)$.

The incidence of health problems is summarized in Table 5. The reason for reporting these data and their statistical analysis is due to the influence they may have had on other results, because there is a relationship between lactation persistency and some of health problems. Although, the results of logistic analysis indicated no significant effect of dietary treatments on health status, but cows fed RPM +RPC had numerically the lowest health problems compared with other groups. This result is consistent with the more persistent early lactation milk yield in RPM+RPC-fed cows. In present study, there were no effects of RPM and RPC supplementations on clinical ketosis and other postcalving metabolic disorders, therefore, RPM+RPC-fed cows did not probably experience the negative energy balance in early lactation weeks. A closer polynomial coefficient to zero would reflect a more persistent early-lactation milk yield. Therefore, RPM + RPC-fed cows had a more persistent $(P<0.05)$ early-lactation milk yield than did other cows. Researches have suggested that early lactation dairy cattle can produce more milk when they receive rumen-protected choline and methionine (SOCHA et al. 2005, SCHEER et al. 2002, SICILIANO-JONES and PUTNAM 2000). In general, it was expected that the costs of health problems, reproductive disorders and feed be lower with the supplementation of RPM+RPC in the diets of dairy cows. The effects of supplementation of RPM and RPC on the lowering of feed costs result from the fact that yield is spread out more evenly for RPM+RPC-fed cows which have more persistent lactation and the 
fraction of feed energy that can be provided by the roughage compared to more expensive concentrates increases. SÖLKNER and FUCHS (1987) used field records on Simmental cows with high and low persistency on concentrate intake. Concentrate was fed according to test-day yield. The high and low group differed by 2.5 phenotypic standard deviations in persistency. When adjusted to a standard 305-day yield of $5500 \mathrm{~kg}$, the high group consumed $659 \mathrm{~kg}$ of concentrate during the 305-day period and the low group $820 \mathrm{~kg}$. The economic importance of this difference will obviously depend on the price difference between concentrate and roughage. PIEPENBRINK and OVERTON (2003) reported a larger number of cows fed higher amounts of RPC treatment seemed to have more difficult transitions, having numerically more incidence of displaced abomasum compared to the cows fed the other treatments. XU et al. (1998) reported the overall incidence of health-related disorders was numerically lowest for cows fed high amount of rumen-protected lysine and methionine.

Table 5

Incidence of health problems in Holstein cows fed supplemental rumen-protected methionine and choline from 4 week prepartum through 14 week postpartum

Gesundheitsbehandlungen im Versuchszeitraum bei den Gruppen

\begin{tabular}{lcccc}
\hline \multirow{2}{*}{ Item } & \multicolumn{3}{c}{ Treatment } \\
& Control & RPM & RPC & RPM + RPC \\
\hline Retained placenta & 4 & 2 & 3 & 0 \\
Mastitis & 2 & 1 & 0 & 0 \\
Displaced abomasum & 0 & 0 & 0 & 0 \\
Uterine problem & 2 & 0 & 0 & 0 \\
Milk fever & 0 & 0 & 0 & 0 \\
Dystocia & 4 & 2 & 2 & 0 \\
Ketosis & 0 & 0 & 0 & 0 \\
Foot/Leg problems & 0 & 0 & 0 & 0 \\
\hline
\end{tabular}

RPM rumen-protected methionine, RPC rumen-protected choline

Consistent with the result of this study, DAVIDSON et al. (2008) reported that multiparous cows consumed more DMI than primiparous cows when their diets supplemented with rumen-protected forms of methionine, choline, and betaine. Contrary to the result of current study, several studies reported that the supplementation of RPC (ZAHRA et al. 2006, PIEPENBRINK and OVERTON 2003, PINOTTI et al. 2002) and RPM (LARA et al. 2006, GIRARD et al. 2005, OVERTON et al. 1996) in the diet of dairy cows had no effect on DMI. But, consistent with the result of this study, XU et al. (1998) reported that lactating dairy cows fed high amount of rumen protected lysine and methionine consumed 3 to $4 \mathrm{~kg}$ more DM than did cows fed the other rations. It seems that the higher milk production of $\mathrm{RPM}+\mathrm{RPC}$ cows compared to other cows is a possible reason for greater DMI in RPM+RPC cows than other groups.

OVERTON et al. (1996) reported that the DMl, yields of milk, CP and percentages of fat and CP in milk were not affected by RPM. However, yields of fat and 3.5\% FCM increased when RPM was fed. The dietary CP and fibre have previously been reported to affect the potential impact of RPM on milk protein (BATEMAN et al. 1999). Low dietary NDF may reduce rumen $\mathrm{pH}$, thereby reducing the efficiency of microbial protein synthesis. Besides, 
high intake of $\mathrm{CP}$ and rumen degradable protein may increase both microbial protein synthesis and rumen $\mathrm{NH} 3$, and thereby mask the potential impact of RPM on milk protein. This is because the greater microbial protein synthesis can reduce the demands for essential AA and hence dilute the potential benefits of RPM. In addition, the higher NH3 may increase ATP cost for urea biosynthesis and excretion by the liver and kidney. However, LEONARDI et al. (2003) found that RPM can improve milk protein content to the same extent regardless of whether it was added to a diet with $14 \%$ or a diet with $18 \%$ CP. Their finding would suggest that extra CP elevates nitrogen excretion (NRC 2001) but may not essentially neutralize the RPM mechanism of action (LEONARDI et al. 2003). Hence, the positive impact of RPM on cow productivity appears to be mediated not exclusively via protein metabolism. In view of the positive ECM response to RPM, the increased milk lactose content may indicate that RPM had a direct positive effect on lactose synthesis in the mammary gland. Typically, the increased milk fat by RPM is not as greatly expected as is the boosted milk protein. To explain, both forage and non-forage fibres could adequately supply milk fat precursors to mammary gland unless rumen fermentation is truly compromised (NRC 2001).

The greater ECM requires greater glucose and AA to uphold. Glucose is essential to provide 1) NADPH for de novo milk fat synthesis and 2) ATP for protein synthesis from AA. The increased ECM suggests that RPM+RPC can positively impact milk energy output when early-lactation curve peaks and drops. Increased yield of 4\% FCM resulted from increases of milk yield, milk fat percentage and DMI. SHARMA and ERDMAN (1988) speculated that, for experiments in which supplemental methionine increased milk or milk fat, choline synthesized from methionine was likely to have been at least partially responsible.

In general, it was expected that the incidence of metabolic and reproductive disorders and negative energy balance that originate from the physiological stress of high milk yield would be lower in dairy cows supplemented with the rumen-protected forms of methionine and choline due to the formation of more persistent lactation curve in dairy cows.

\section{References}

Allen OB, Burton JH, Holt JD (1983) Analysis of repeated measurements from animal experiments using polynomial regression. J Anim Sci 57, 765-70

AOAC (Association of Official Analytical Chemists) (2000) Official Methods of Analysis, 17th ed. AOAC, Gaithersburg, MD, USA

Baffour-Awuah O, Brotherstone S, Hill WG (1996) Genetic analysis of test day production in second lactation of British Holstein-Friesian cows. Arch Tierz 39, 213-26

Bateman HG, Spain JN, Kerley MS, Belyea RL, Marshall RT (1999) Evaluation of ruminally protected methionine and lysine or blood meal and fish meal as protein sources for lactating Holsteins. J Dairy Sci 82, 2115-20

Davidson S, Hopkins BA, Odle J, Brownie C, Fellner V, Whitlow LW (2008) Supplementing limited methionine diets with rumen-protected methionine, betaine, and choline in early lactation Holstein cows. J Dairy Sci 91, 1552-9

Dekkers JCM, Jamrozik J, Ten Hag JH, Schaeffer LR, Weersink A (1996) Genetic and economic evaluation of persistency in dairy cattle. Interbull Bulletin 12, 97-102

Dekkers JCM, Ten Hag JH, Weersink A (1998) Economic aspects of persistency of lactation in dairy cattle. Livest Prod Sci 53, 237-52 
Gengler N (1995) Use of mixed models to appreciate the persistency of yields during the lactation of milk yield. Ph.D. thesis, Faculte' Universitaire des Sciences Agronomiques de Gembloux. Communaute' Franc, aise de Belgique

Gengler N (1996) Persistency of lactation yields: a review. In: Proc Int Workshop Genet Impr Funct Traits in Cattle, Gembloux, Belgium. 21-23 January 1996. Interbull Bulletin No. 12. Department of Animal Breeding and Genetics SLU, Uppsala, Sweden, 87-96

Grossman M, Hartz SM, Koops WJ (1999) Persistency of lactation yield: a novel approach. J Dairy Sci 82, 2192-7

Girard CL, Lapierre H, Matte JJ, Lobley GE (2005) Effects of dietary supplements of folic acid and rumenprotected methionine on lactational performance and folate. J Dairy Sci 88, 660-70

Jakobsen J, Madsen P, Jensen J, Peersen J, Cristiensen LG, Sorensen DA (2002) Genetic parameters for milk production and persistency for Danish Holsteins estimated in random regression models using REML. J Dairy Sci 85, 1607-16

Kocak O, Ekiz B (2008) Comparison of different lactation curve models in Holstein cows raised on a farm in south-eastern Anatolia region. Arch Tierz 51, 329-37

Lara A, Mendoza GD, Landois L, Barcena R, Sanchez-Torres MT, Rojo R, Ayala J, Vega S (2006) Milk production in Holstein cows supplemented with different levels of ruminally protected methionine. Livest Sci 105, 105-8

Leonardi C, Stevenson M, Armentano LE (2003) Effect of two levels of crude protein and methionine supplementation on performance of dairy cows. J Dairy Sci 86, 4033-42

Morris TR (1999) Experimental design and analysis in animal sciences. CAB Int, Wallingford, UK, 113-18

National Research Council (1998) Dietary reference intakes for thiamin, riboflavin, niacin, vitamin B6, folate, vitamin B12, pantothenic acid, biotin, and choline. Nat Acad Sci, Washington, DC, USA

National Research Council (2001) Nutrient requirements of dairy cattle. 7th ed. Nat Acad Sci, Washington, DC, USA

Overton TR, LaCount DW, Cicela TM, Clark JH (1996) Evaluation of a ruminally protected methionine product for lactating dairy cows. J Dairy Sci 79, 631-8

Overton TR, Emmert LS, Clark JH (1998). Effects of source of carbohydrate and protein and rumenprotected methionine on performance of cows. J Dairy Sci 81, 221-8

Piepenbrink MS, Overton TR (2003) Liver metabolism and production of cows fed increasing amounts of rumen-protected choline during the periparturient period, J Dairy Sci 86, 1722-33

Pinotti L, Baldi A, Dell'Orto V (2002) Comparative mammalian choline metabolism with emphasis on the high-yielding dairy cow. Nutr Res Rev 15, 315-31

Pryce JE, Veerkamp RF, Thompson R, Hill WG, Simm G (1997) Genetic aspects of common health disorders and measures of fertility in Holstein Friesian dairy cattle. Anim Sci 65, 353-60

SAS (2002) SAS User's guide v. 9.1: Statistics. SAS Institute, Inc, Cary, NC, USA

Scheer WA, Lucy MC, Kerley MS, Spain JN (2002) Effects of feeding soybeans and rumen protected choline during late gestation and early lactation on performance of dairy cows. J Dairy Sci 85 (Suppl 1), 276

Sharma BK, Erdman RA (1988) Effects of high amounts of dietary choline supplementation on duodenal choline flow and production responses of dairy cows. J Dairy Sci 71, 2670-6

Siciliano-Jones J, Putnam D, (2000) Rumen-stable choline use in transition dairy cows improves early lactation milk yield, J Dairy Sci 83 (Suppl 1), 237

Socha, M. T., Putnam DE, Garthwaite BD, Whitehouse NL, Kierstead NA, Schwab CG, Ducharme GA, Robert JC (2005) Improving intestinal amino acid supply of pre- and postpartum dairy cows with rumen-protected methionine and lysine. J Dairy Sci 88, 1113-26

Sölkner J, Fuchs W (1987) A comparison of different measures of persistency with special respect to variation of test-day milk yields. Livest Prod Sci 16, 305-19

Steel RGD, Torrie JH (1987) Principles and procedures of statistics. 2nd rev. ed. McGraw-Hill Inc, USA

Swalve HH (1995) Test day models in the analysis of dairy production data - a review. Arch Tierz 38, 591-612

Swalve HH, Guo Z (1999) An illustration of lactation curves stratified by lactation yield. Arch Tierz 42, 515-25

Swalve HH (2000) Theoretical basis and computational methods for different test day genetic evaluation methods. J Dairy Sci 83, 1115-24

Takma C, Akbas Y (2007) Estimates of genetic parameters for test day milk yields of a Holstein Friesian herd in Turkey with random regression models. Arch Tierz 50, 327-36 
Tekerly M, Akinci Z, Dogan I, Akcan A (2000) Factors affecting the shape of lactation curves of Holstein cows from the Balikesir province of Turkey. J Dairy Sci 83, 1381-6

Van Soest PJ, Robertson JB, Lewis BA (1991) Methods for dietary fiber, neutral detergent fiber, and nonstarch polysaccharides in relation to animal nutrition, J Dairy Sci 74, 3583-97

Xu S, Harrison JH, Chalupa W, Sniffen C, Julien W, Sato H, Fujieda T, Watanabe K, Ueda T, Suzuki H (1998) The effect of ruminal bypass lysine and methionine on milk yield and composition of lactating cows. J Dairy Sci 81, 1062-77

Zahra LC, Duffield TF, Leslie KE, Overton TR, Putnam D, LeBlank SJ (2006) Effects of rumen-protected choline and monensin on milk production and metabolism of periparturient dairy cows. J Dairy Sci $89,4808-18$

Received 2 June 2009, accepted 30 April 2010.

Corresponding author:

MEHRNAZ ARDALAN

email:m.ardalan87@gmail.com

Department of Animal Science, University College of Agriculture and Natural Resources, University of Tehran, Karaj, Iran 